\title{
Supply Chain Security: International Practices and Innovations in Moving Goods Safely and Efficiently-A Review
}

\author{
Jennifer Crawford Leonard
}

Received: 31 March 2010 / Accepted: 16 April 2010 / Published online: 19 May 2010

(C) Springer Science+Business Media, LLC 2010

WOW! This book is a must read for anyone involved in the transportation of goods! The two-volume series is well organized and written so it is easy to understand for both academics and professionals alike. The discussions of Homeland Security, piracy, and terrorism are timely and provide a great education on these little discussed topics. After all, we all know it will never happen to us! The table in the "Commercial Vehicle Safety" chapter is compelling-both informative and scary!

Environmental issues are not generally considered in supply chain risk beyond those of "routine" weather disruptions. The chapter dealing with this issue is complete and well informed!

Everyone who teaches supply chain management, risk and assessment, and strategic management should add these volumes to his or her library and include supply chain security topics in the class!

Professors - reach the next generation! Professionals involved in storing and moving goods — take note! Manager and CEOs — be aware! The risks to your supply chains are higher than they seem!

J. C. Leonard $(\bowtie)$

College of Business, Montana State University Billings, 1500 University Drive - McD 211, Billings, MT 59101, USA

e-mail: jleonard@msubillings.edu 